\title{
Pedagogical Translation Use by Scientific Approach in Teaching English
}

\author{
Masitowarni Siregar \\ Universitas Negeri Medan, Indonesia \\ siregarmasitowarni@yahoo.com
}

\begin{abstract}
This research was conducted to find out the way the English teachers used translation and the reasons the teachers used it in the instructional activity with scientific approach. The information were obtained from the English teachers in MAN Medan. Descriptive qualitative research design was utilized in answering the research's problems. No treatment in this study. Following descriptive qualitative research this study provided description of a phenomenon that occurred naturally without any an experiment intervention or an artificially contrived treatment. Observation and interview were utilised as the techniques of collecting data. The finding indicated that there were three English teachers in teaching English used scientific approach in the process of using and correcting words, phrase or sentences messages, elaborating structure and classroom management. Furthermore, the reasons of pedagogical translation use were to help communication in the classroom, develop the students teacher relation and facilitate foreign langaage understanding.
\end{abstract}

Keywords: pedagogical translation; scientific approach; Teaching English

\section{Introduction}

Translation has the significant role in increasing students' skills to master English. Based on Researcher Ross (2000), translation is very critical language skill except listening, reading, speaking, and writing because translation also increase interaction and understanding. Translation Operation needs interchange and colaboration among learners and learners and instructors of English instruction and, which is useful in improving students' ability in foreign language teaching. Translation is not only used by all professionals, but it is also used English teachers during academic activities on applied linguistics, English instruction and translation in different situation and aspect (Mohaamed, 2014). However, the translation use is debatable since it is often argued in different sides. First, translation can not be conducted in a foreign language teaching because it creates language interference (Shiyab, 2006). In a foreign language, translation can make inhibit thinking and produce more complex bilingualism than interrelate bilingualism.

This is in line with Mehrabi (2014) who stated that teachers in Teaching English have been reconsidering the translation use for improving the purposes of learning. Furthermore, Cook (2001) stated that translation process were conducted in English interactional acativities which can be used as the learning resources, if it used judiciously it can assist Teaching English in the classroom.

Some statements above implied that the translation use in Teaching English allow some chances to the students in encouraging the students' interests in practicing English competencies namely, reading, writing, listening, speaking, vocabulary, and grammar. Translation is also used to assist the students in transforming students' vocabulary and sentence structure knowledge from source into target language (Pan, Yi-chun, 2012). Therefore, the functions of translation is to develop students' language skills in communication, even translation use is often criticized in different arguments. 
First, translation can not be used in Teaching English because it is considered to provide a negative interference. However, some practitioners opposed the translation use, since the translation existence in teaching English by practicing translation as a basis for acquiring from source into target language.

Cook (2009) stated that translation which was often criticized its function in English learning usually associated with the use of Grammar-Translation Method, with the objection of maximizing the rehearsal of translation activities became the primary strategiess of English instruction.

During the time of $20^{\text {th }}$ century, it was well known that Grammar Translation Method (GTM) was a good way to be highly thought of and used in language teaching. However, some translation practitioners opposed this way and criticize the inefectiveness of its elemental and use in improving students' English skills and resulted that speaking skill of the language was very useful. Based on data found, MAN teachers prefer to eliminate first language and practice translation in English classroom contexts.

Another perspective which is GTM opponent argued that the mother tongue use as inefficient in the English language instruction, and therefore, the translation utilization their experiences in expressing their thought and feeling freely in the target language (Mehrabi, 2014).

In addition, Shiyab (2006) stated that translation can not be used in Teaching English because of the existence of language intrusion. Translation provided distructive opinion in Teaching English and come up with more complex bilingualism than interrellate bilingualism. In addition to this, the translation use in English instruction process might obstruct in achieving the students' practice automatically.

Furthermore, Duff (1994) provided the other reasons why teachers used translation as a strategy in Teaching English. Process of Translation is is very contextual and limited in two capabilities such as, reading and writing. The translation is not an interactive competency because it did not demand speaking competencies (productive skill). Besides, the source language use was needed, which is undesirable. It is not a productive utilization when the translation is utilized in assisting the learner to share their precious from first language into foreign language being learned.

Utilization of translation in Indonesia has actually been actualized in English instructional process by the foreign language instructors. To achieve the goal of both receptive and productive skills, teachers have used translation to ensure that students understand toward what teachers explain. It is eventually helpful and useful. However, the teachers do not realize the usefulness of the translation. Further, there is no research on how translation use in English language instructional implementation in Indonesia and the teachers' perception about the translation use which claimed as an invalid tool of teaching and learning practice.

Based on curriculum 2013, English instructional activities is carried out by utilizing scientific approach as a teaching strategy which applies and conducts scientific stages in educating subjects at senior high school in Indonesia. Kemdikbud (2013) and Hosnan (2014) stated that there are five steps of applying scientific approach in teaching learning process, they are observing, questioning, experimenting, associating, and communicating. In Teaching English through scientific approach, there must be translation use which contains detailed instructions in Teaching English starting from observing to communicating in the classroom. 
It had been noticed that English teachers of Senior High School in Medan used translation in the classroom. The translation use is very useful in facilitating teaching and learning process especially if the students are in low-level. The teachers also argued that the translation was helpful for the students in MAN Medan especially in comprehending of clarifying grammatical and lexical concepts. Therefore, the teacher conducted translation as a method to convince the learners getting the materials given. Furthermore, the instructors used translation as an instrument to link the relationship among instructors and leaners called as pedagogical translation.

This research was aimed at investigating elements of translation utilized by English instructors in MAN Medan. This research was conducted to find out how the English instructors utilized pedagogic translation based on scientific approach and why the teachers used pedagogic translation as a technique in English language instruction.

\section{Literature Review}

Based on language experts translation depends on how the learners view the language and translation as one of the techniques in foreign language instruction. Furthermore, translation is a way of conveying message from one source language to another target language. Thus, translation is transferred not the form of the source text (ST) to the foreign language being learned but meaning expressed essentially.

Based on Larson (1991) translation is an activity related to the hypothesis that is possible to understand the massage of a text from its forms and reproduces that meassage with the natural way of expressing the same meaning in the target language. Based on explanation above, the translator somehow may put an end the true message of the source language to get a reasonable sense of the target language.

Furthermore, the particular instance of translation is when the teachers utilization of the students' first language which is crucial in beneficial for the learners in the English as a foreign language in the classroom. An example of these is while expressing and assessing words and sentences meaning (Cook , 2001)

This means translation is very helpful in elaborating structure of language. Cook (2001) also stated that first language could be productively utilised in management classroom involving when the teachers organized assignment and rules to be used in the instructional process.

Three grounds for utilization of first language in the teaching process by the English language instructors (Harbord,1992). They are facilitating communication, facilitating teacher-student relationships, and facilitating the learning of foreign language. In addition, Cook (2001) stated that the teachers should use first language to show the meaning and organize the classroom. Students may use their first language to develop their understanding of the words to understand the lessons and for learning collaboratively with their peers. Probably economizing time in the foregin language instructional process is the best motive in utilizing first language (Harbord, 1992).

Therefore, the research aims at investigating the use of to examine the use of translation in foreign language instruction. Translation is a basic process and unavoidable in foreign language instruction. In this way, Mohamed (2014) argued the utilization of translation can not be considered as a negative interference but also as an effective method in Teaching English. Mohamed (2014) also stated the ustilization of translation could help the 
instructors directed learner's focus to comprehend syntactic errors, such as, word order, submisssive configuration and time-tense distinctions as well conditional sentences.

\subsection{Translation and Teaching English}

The use of translation in Indonesia has actually been actualized in English language instructional process. To achieve the goal of both receptive and productive skills, teachers have used translation to ensure that students understand toward what teachers explain. It is eventually helpful and useful. However, the teachers do not realize the usefulness of the translation. Further, there is no research on how translation use in language instructional process in Indonesia and the teachers' perception about the translation use which claimed as an invalid instrument or tool in English language instructional process.

Furthermore, Mohamed (2014) concluded there were some benefits in utilizing translation in English language instruction. It caused advanced scientits trying to express the perspectives to support the translation use in language teaching and learning process.

In line with the idea mentioned previously, there are some perspectives which support the conclusion of the translation.

A. Translation has pedagogical benefits toward teachers and students

B. Translation could be utilized to be direct method teaching and an exclusive alternative in Teaching English. The translation process might include spoken and written exercise, and emphasize on interrelated discourse or massage. The translation becomes successful translation if there are criteria based on formal lexical and grammatical.

In addition to that, translation authors and invesigators concur on a basic notion of translation itself which is translation might be helpful in various activities and phases in Teaching English. It was clear that the translation use in Teaching English and learning is an effective method both pedagogically and educationally (Mohamed, 2014: 32).

\subsection{Reasons of Using Translation in Teaching}

Many researchers have shown translation use as the way to use first language in foreign language well. As an example, Tang (2002) usually utilized first language for slow language learners make orde, to elaborate senses of words, to describe complicated notion and to elaborate complicated structure elements. Learners comprehended more when translation use to explain about the language.

Alshammari (2011) and Machaal (2012) were in opinion that the translation utilization could also make instructors' time of elaborating more efficient, develop the learners' comprehending and increase the quality of the instructional process. Utilization of first language as a translation method proof to be efficient in language instruction. Other positive point of using first language is developing proper association among instructors and students. Misunderstanding can be avoided (Turgut and İrgin, 2009). Instructors and students connection runs well and smooth (Nation, 2003). Therefore, learners didn't hesitate to demand help if they have problems in English learning.

Three grounds for the utilization of first language in the teaching process (Harbord,1992). They are facilitating communication, facilitating teacher-student relationships, and facilitating the learning of L2. In addition, Cook (2001) stated that the teachers should use first language to show the meaning and organize the classroom. Students may use their first language to develop their understanding of the words to understand the lessons and for learning collaboratively with their peers. Probably 
economizing time in the language instructional process is the best motive in utilizing first language (Harbord, 1992).

\subsection{Pedagogical Translation use based on Scientific Approach in Teaching English}

Curriculum 2013 demands the use of scientific approach in the process of all subjects in Indonesia including English subject. Long (2014) stated that scientific approach is activity seek out information and testing ideas by experimentation arrive at conclusion accordingly. of scientific approach in the classroom process based on Curriculum 2013. The stages observing, questioning, experimenting, associating and communicating. In doing scientific approach, the pedagogic translation is conducted. Therefore, Dagilienè (2012) stated translation assisted the students to achieve, grow and confirm the students' command and skill in studying English.

By using translation, it made the students communicating in both ways namely, into and from English as a foreign language. Thus, it was an effective method for the teacher to conduct translation in Teaching English in order that the students can master English skills and increasing their interest toward English itself.

Pedagogical translation use assumed for practicing both oral and written skills use and translation activities can be conducted based on the teaching targets designed by the teachers.

\section{Research Method}

The study aims at investigating the English instructors' use and reasons of translation method. The subject of the study was the English teachers in MAN Medan. Descriptive qualitative research was conducted in answering the research's problems and no experimentation in the study. The design of the study was descriptive qualitative which elaborated of exististing condition without any intervention or an treatment (Bogdan \& Biklen, 1992). The instruments of gathering information were observation and interview.

\section{Discussion}

Translation has the significant role in improving students' skills to master English. Based on Researcher Ross (2000), translation is the most important language skill except listening, reading, speaking, and writing because translation also increase competency. In the process of translation, it needs relations and cooperation among students, which is useful in improving students' ability in instruction. Translation is not only used by all professionals, but it is also used English teachers during seminars on linguistics, language instruction and translation in different situation and aspect (Mohaamed, 2014). Translation is as a teaching technique to make learners understand quickly.

The research emphasized that translation is useful in language instruction. The teachers often utilised the translation. Furthermore, the particular instance of translation is when the teachers use of the students' first language to help the learning process. For instance is while bringing and checking words and sentences meaning (Cook , 2001)

Based on the data gathered, there were 51 times of utilization of translation found during the English instruction. Figure 1 showed pedagogical translation use in Teaching English based on scientific approach. 


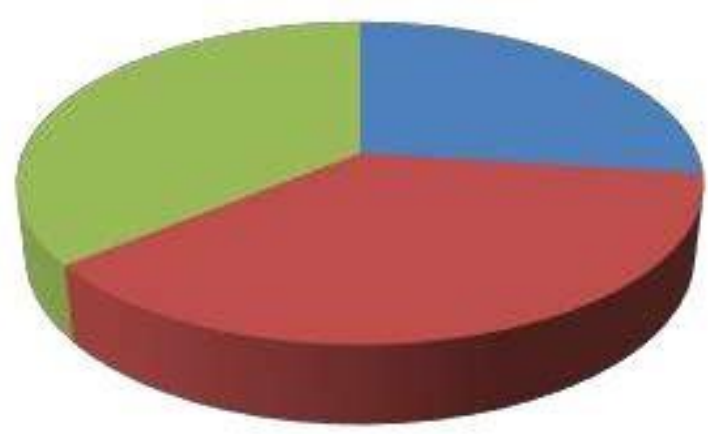

Figure 1. The Use of Translation

Figure 1 showed the number of translation use in Teaching English by using scientific approach was 51 times. Then the dominant step using pedagogic translation was associating.

The data also shows that in scientific approach activities, experimenting and associating activities were more dominant activities that use pedagogical translation than observing, questioning and communicating. The figure 2 below showed the percentage of pedagogic translation in scientific approach activities.

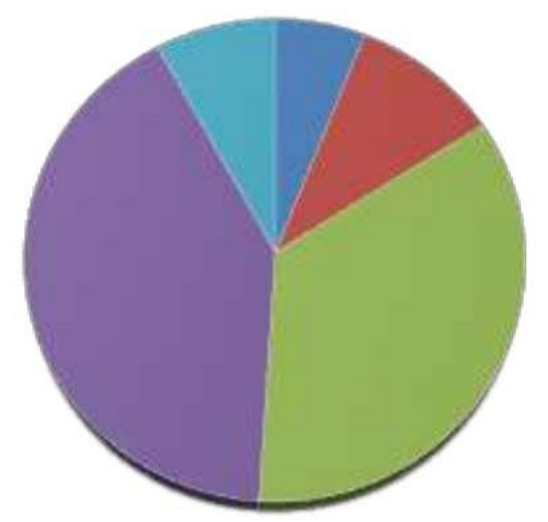

Figure 2. The Use of Translation

In answering the research problem about the reasons why the English teachers used pedagogical translation, the researcher interviewed the teachers. There were some reasons of the teachers in using pedagogical translation in scientific approach in Teaching English. They were: (1) The students are weak in comprehending English; (2) Translation can improve the students' ability to learn English; (3) Translation provides contrastive knowledge; (4) translation makes the teaching and learning process to be more efficient because it saves time during teaching and learning process; (5) Translation is an effective method to explain some difficulties in Teaching English.

Furthermore, teachers used translation in Teaching English since the translation are intended such as, (1) to assist learners elaborate the a word, phrase, idiom or sentence meaning; (2) to asses learners' competency; (3) to develop learners' vocabulary; (4) to develop students' skills of contrastive analysis; (5) to test students' learning; (6)to confirm learners' English proficiency. 
The explanation above related with the previous study by Mohamed (2014). Mohamed (2014) stated that using translation can not be considered as a negative interference but also as an effective method in Teaching English. Mohamed (2014) also stated that utility of translation can assist the teachers directed learners' focus to comprehend syntactic errors, such as, word order, passive construction and time-tense distinctions or conditional sentence. The information gathered indicated The findings are Translation was utilized by the English teachers in MAN Medan; Translation assisted the students to solve their problems in learning English. Furthermore, pedagogical

translation solve problems in explaining things in English; Then teachers used translation in instructional activities of English subject as a method to check learners' comprehension, to assist the students clarifying the linguistic units meaning, to expand learners' vocabulary, to grow learners' skills of contrastive analysis, to test learners' learning, and to strengthen learners' command of English.

\section{Conclusion}

Based on the discussion above, there were two results of this research conducted.

1. Pedagogical Translation was utilized in the instructional process based on scientific approach. It was assumed as an effective method in teaching English. Then, in scientific approach activities experimenting and associating activities were more dominant activities that use pedagogical translation than observing, questioning and communicating

2. There were some reasons of the teachers in using pedagogical translation in scientific approach in Teaching English. They were: (1) The students are weak in comprehending English; (2) Translation can improve the students' ability to learn English; (3) Translation provides contrastive knowledge; (4) translation makes the teaching and learning process to be more efficient because it saves time during teaching and learning process; (5) Translation is an effective method to explain some difficulties in Teaching English.

\section{References}

Academic Writing: A practical Guide for Students. London: Rouletdge.

Arikunto, S. (2006). Metodologi Penelitian. Yogyakarta: Bina Aksara. Bailey, S.

Blackman, Natalia. (2013). EFL teachers' perceptions on the use of L1 in a primary and secondary classroom.A dissertation.University of Edinburgh.

Bogdan, Charles R. \& Kopp Sari Biklen. (1998). Qualitative Research in Education: an introduction to theory and methods. USA.

Brown, H. (2001). Teaching by principles (2nd ed). Englewood Cliffs: Prentice Hall.

Calis, E \&Kenan, D. (2012). The Use of Translation in EFL Classes as L2 Learning Practice. Social and Behavioral Sciences Procedia, 46, 5079-5084.

Cook, G. (2010). Translation in Language Teaching. Oxford and New York: Oxford University Press.

Cook, V. J. (2001), . Using the first language in the classroom. Canadian Modern Language Review, 57(3), 184-206. 
Dagilienè, I. (2012). Translation as a Learning Method in English Language Teaching.Studies About Languages. 21, 124-129.

Dirgeyasa, I Wy. (2014). College Academic Writing: A Genre Based Perspective. Medan: Unimed Press.

Emzir.(2015). Teoridan Pengajaran Penerjamahan. Jakarta: Rajawali Pers.

Fernández-Guerra, A. (2014). The Usefulness of Translation in Foreign Language Learning: Students' Attitudes. International Journal of English Language \& Translation Studies, 2(1), 153-170.

Florentina, G. (2007). The Role of Translation in Foreign Language Teaching.University of Pitesti.

Flores, K. F. (2015). Second Language Pedagogy and Translation: The Role of Learners' Own-language and Explicit Instruction Revisited. 6(1), 51-65.

Griffe, Dale T. (2012). LanguageTeaching Research \& Language Pedagogy. London. WileyBlackwell, A. JhonWilet\& Sons, Ltd., Publication.

Harmer, J. (1998).How to Teach English: An Introduction to the Practice of English Language Teaching. (2nd ed).Longman.

Johnson, A.P. (2008). Teaching Reading and Writing: A Guidebook for Tutoring and Remediating Students. Plymouth: Rowman and Littlefield Education.

Kelly, N \& Jennifer, B. (2015).Translation as a pedagogical tool in the foreign language classroom: A qualitative study of attitudes and behaviours. Language Teaching Research.19(2), 150-168.

KheradRanjbar, M. (2015).The Comparative Impact of Reading Comprehension and Translation Practices on EFL Learners' Grammar Achievement.In : Journal of Studies in Education. 5(4), 51-73.

Kim Pham, C. T. (2017.) Reading Comprehension and Translation Performance of English Linguistics Students of Hung Vuong University: A Correlational Study. International Journal of English Language \& Translation Studies, 5(3), 79-85.

Lodico, M., Spaulding, D., \&Voegetl, K. (2010). Methodsin educational research: From theory to practice. San Fransisco, CA: John Wiley \& Sons, Inc.

M. Zaim. (2017). Implementing Scientific Approach to Teach English at Senior HighSchool in Indonesia. Canadian Center of Science and Education, 13(2), 33-40.

Maxwell, J. A. 1996. Qualitative Research Design: An Interactive Approach. Thousand Oaks, CA: Sage.

Mehrabi, B. A. (2014). Pedagogical Utility of Translation in Teaching Reading Comprehension To Iranian EFL Learners. International Journal of Language Learning and Applied Linguistics World, 5(2), 381-395.

Mohamed Azrien, M. A \&Shukeri M. (2014). The Use of First Language in Arabic Language Classroom: A Teaching Buttress or a Learning Obstacle. Journal of Islamic Studies and Culture, 2(2), 55-70.

Mohamed, J. (2014). Use of Translation in the Classroom by EFL Teachers in Libya (A descriptive study). Arab World English Journal, (3), 27-40.

Moleong.(1998). MetodologiPenelitianKualitatif. CV. RemajaRosdakarya, Bandung. Nation, I.S.P. (2009). Teaching ESL/EFL Reading and Writing. New York: Routledge. National Education Association. (2000). "Ten Proven Principles for Teaching Reading”, in: State of the Art (ed): Transforming Ideas for Teaching and Learning to Read. Department of Education: U.S.

Newmark, P. (1988). A Textbook of Translation. London: Prentice Hall. 
Nida, E. A. \& Charles, R. T. (1969).The Theory and Practice of Translation. Leiden: EJ.Brill. Pan, Y. C. \& Yi. C. P. (2012). The Use of Translation in the EFL Classroom.Philippine ESL Journal, 9, 4-23.

Peverati, Costanza. (2015). Translation in University Foreign-Language Curricula: An Analysis Of Teachers' Attitudes, With Reference To Vocational And Transferability Criteria. A Doctoral Thesis. Universitat Rovira I Virgili.

RestiMartanti, I. F. (2013). Improving the Teaching Of Reading By Using Silent Card Shuffle Strategy (Scss) To The Eighth Grade Students Of Smpn 1 Seyegan In The Academic Year 2012/2013. A Thesis. Yogyakarta: English Language Education Department, Faculty of Languages and Arts, State University of Yogyakarta.

Richards, J. C., \& Lockhart, C. (1996). Reflective teaching in second language classrooms (6th ed). New York: Cambridge University Press

Ross, N. J., (2000). Interference and Intervention: Using Translation in the EFL Classroom. Modern English Teacher, 9(3), 61-66.

Shiyab, S. (2006). A Textbook of Translation: Theoretical and practical implications. Antwerp: Garant.

SilabusMata Pelajaran Sekolah Menengah Atas/Madrasah Aliyah/Sekolah Menengah Kejuruan/Madrasah Aliyah Kejuruan (SMA/MA/SMK/MAK): Mata Pelajaran Bahasa Inggris. (2016). Kementerian Pendidikan Dan Kebudayaan Jakarta.

Silviana, E. (2008). An Analysis of Students' Difficulties in Translating Narrative Text (A case study at eleventh grade of SMK Hass Ashabulyamin Cianjur). English Education Study program Language and Arts Department, (STKIP) Siliwangi Bandung.

Siregar, M. (2018). Bahan Ajar Translation I: Latihan Translation Berbasis Pengajaran Bahasa Inggris sebagai Bahasa Asing. Medan: Unimed Press

Sugiyono. 2008. Metode Penelitian Kuantitatif Kualitatif dan R\&D. Bandung: Alfabeta. Topolska, P.J. (2010). Use of L1 and Translation in The Efl Classroom. 11-25.

Wiersma, W. (1991). Research Method in Education: An Introduction USA: Allyn and Bacon 